International Oceans, Environment, Health, and Aviation LaW

\title{
U.S. Trade Representative Holds Environmental Consultations with South Korea Regarding Illegal, Unreported, and Unregulated Fishing
}

doi:10.1017/ajil.2020.18

The United States requested environmental consultations with South Korea under the United States-Korea Free Trade Agreement (KORUS) in September 2019. This request occurred on the same day as the release of a report to Congress raising concerns about South Korea's response to illegal, unreported, and unregulated fishing. Following the consultations, South Korea amended its law regulating the Korean fisheries industry in order to make more enforcement mechanisms available.

On September 19, 2019, the U.S. National Marine Fisheries Service released its biennial report to Congress on fisheries management, which identified South Korea and two other nations as failing to adequately regulate illegal, unreported, and unregulated fishing. ${ }^{1}$ The report noted that the treaty monitoring body for the Convention on the Conservation of Antarctic Marine Living Resources had determined that, in 2017, two South Korean fishing vessels had impermissibly set "longline gear within 24 hours of a notified fishery closure." 2 South Korea had ordered the boats to leave and suspended one boat's license for two months, but it did not impose fines or seize the illegal catch. ${ }^{3}$ This was because its Distant Water Fisheries Development Act provided only for criminal penalties, which it chose not to pursue in response to the 2017 incident. ${ }^{4}$ The 2019 report to Congress noted that during prior consultations with both the treaty monitoring body and U.S. negotiators, South Korea had "recognized the need for administrative enforcement authority to address cases . . that are inappropriate for criminal prosecution, as well as for enabling the government to deprive the violators of the economic benefit of their violations." 5 South Korea represented that it would soon be amending its Distant Water Fisheries Development Act to incorporate such changes. ${ }^{6}$

Although the 2019 report recognized that South Korea was already on its way to reforming its laws, the Office of the U.S. Trade Representative (USTR) requested consultations with South Korea on this subject on the same day that the report was released.7 The USTR invoked

\footnotetext{
${ }^{1}$ Nat'l Oceanic \& Atmospheric Admin., Improving International Fisheries Management: 2019 Report to Congress 27-30 (2019), at https://www.fisheries.noaa.gov/foreign/international-affairs/identification-iuu-fishing-activities [https://perma.cc/RTN5-LQEM] [hereinafter 2019 NOAA Report] (also identifying Ecuador and Mexico); see also NOAA Press Release, NOAA Fisheries Releases Report to Congress Identifying Three Nations for Reported IUU Fishing Activities (Sept. 19, 2019), at https://www.fisheries.noaa.gov/feature-story/ noaa-fisheries-releases-report-congress-identifying-three-nations-reported-iuu-fishing [https://perma.cc/W578DB6B]. This biennial report to Congress is required under the Magnuson-Stevens Fishery Conservation and Management Reauthorization Act of 2006. Pub. L. No. 109-479, \$ 403, 120 Stat. 3575, 3626-27 (2007).

2019 NOAA Report, supra note 1 , at 30.

${ }^{3} \mathrm{Id}$.

${ }^{4} I d$.

${ }^{5} I d$.

${ }^{6} I d$.

7 Office of the U.S. Trade Representative Press Release, USTR to Request First-Ever Environment Consultations Under the U.S.-Korea Free Trade Agreement (KORUS) in Effort to Combat Illegal Fishing
} 
the environmental chapter of KORUS, which requires that "a party shall adopt, maintain, and implement laws, regulations, and all other measures to fulfill its obligations under the multilateral environmental agreements listed in Annex 20-A," including the Convention on the Conservation of Antarctic Marine Living Resources. ${ }^{8}$ U.S. officials then met with South Korean counterparts in Seoul on October 17, 2019, and, within a few weeks of this meeting, South Korea amended its Distant Water Fisheries Development Act to encompass administrative remedies. ${ }^{9}$

U.S. Trade Representative Robert Lighthizer asserted that “the Trump Administration's strong commitment to using tools such as environmental monitoring and enforcement provisions under our trade agreements can produce real results that help protect and conserve our ocean resources." 10 These "first ever environment consultations" under KORUS came less than a year after the USTR had pursued environmental consultations under the U.S. free trade agreement with Peru. ${ }^{11}$ In 2019, there were thirteen U.S. free trade agreements that featured environment chapters, including the not-yet-in-force United States-MexicoCanada Agreement (USMCA). ${ }^{12}$ In December of 2019, the Trump administration conceded to more robust enforcement mechanisms for the USMCA's environmental provisions in order to ensure its approval in the House of Representatives. ${ }^{13}$

(Sept. 19, 2019), at https://ustr.gov/about-us/policy-offices/press-office/press-releases/2019/september/ustrrequest-first-ever [https://perma.cc/KLX3-DT9V].

${ }^{8}$ U.S.-Kor. Free Trade Agreement, Art. 20.2, Annex 20-A at (1)(a), June 30, 2007, 125 Stat. 428, available at https://ustr.gov/sites/default/files/uploads/agreements/fta/korus/asset_upload_file852_12719.pdf [https:// perma.cc/YA7G-L8GU]; see also id. Art. 20.9(1) (providing that "a Party may request consultations with the other Party regarding any matter arising under this Chapter").

${ }^{9}$ See Office of the U.S. Trade Representative Press Release, USTR Welcomes Passage of Amendments to Korea's Distant Water Fisheries Development Act Following First Ever Environment Consultations Under the United States-Korea Free Trade Agreement (Nov. 1, 2019), at https://ustr.gov/about-us/policy-offices/pressoffice/press-releases/2019/november/ustr-welcomes-passage-amendments [https://perma.cc/5Y62-AVK6].

${ }^{10} \mathrm{Id}$.

${ }^{11}$ Id.; Jean Galbraith, Contemporary Practice of the United States, 113 AJIL 640, 640-41 (2019) (discussing the consultations with Peru). The USTR has also met in recent years with counterparts in Singapore to discuss compliance with the environmental chapter of the U.S.-Singapore Free Trade Agreement. Office of the U.S. Trade Representative Press Release, Joint Statement on the United States-Singapore Free Trade Agreement Environment Chapter Meeting (Oct. 5, 2017), at https://ustr.gov/about-us/policy-offices/press-office/pressreleases/2017/october/joint-statement-united-states-1 [https://perma.cc/25JN-USRY].

${ }^{12}$ See Office of Envtl. Quality \& Transboundary Issues, Current Trade Agreements with Environmental Chapters, U.S. DeP'T OF STATE (Feb. 11, 2019), at https://www.state.gov/key-topics-office-of-environmental-quality-and-transboundary-issues/current-trade-agreements-with-environmental-chapters [https://perma.cc/6MGWFVRE].

${ }^{13}$ See Jean Galbraith, Contemporary Practice of the United States, 114 AJIL 137, 141 (2020) (discussing the Trump administration's actions in securing congressional approval for the USMCA); see also Protocol of Amendment to the Agreement Between the United States of America, the United Mexican States, and Canada, Dec. 10, 2019, available at https://ustr.gov/sites/default/files/files/agreements/FTA/USMCA/Protocolof-Amendments-to-the-United-States-Mexico-Canada-Agreement.pdf [https://perma.cc/5W6S-GHVL] (containing the changes made in December 2019). 